\title{
Quality of herbage at different latitudes
}

B. Deinum ${ }^{1}$, J. de Beyer ${ }^{1}$, P. H. Nordfeldt ${ }^{2}$, A. Kornher ${ }^{3}$, O. $\emptyset_{\text {stgård }}{ }^{4}$ and G. van Bogaert $^{5}$

1 Department of Field Crops and Grassland Science, Agricultural University, Wageningen, Netherlands

2 Former student of the Department of Field Crops and Grassland Science, Agricultural University, Wageningen, Netherlands

3 Division for Forage Production, Department of Plant Husbandry, Uppsala, Sweden

4 Holt Agricultural Research Station, Tromsö, Norway

5 Goverment Plant Breeding Station, Merelbeke, Belgium

Accepted: 2 March 1981

Key-words: herbage, timothy, latitude, Phleum pratense

\section{Summary}

In a cooperative experiment yield and herbage quality of timothy (Phleum pratense L.) was measured during the uninterrupted growth of the first cut at 6 latitudes ( 51 to $69^{\circ} \mathrm{N}$ ). Rate of production was greatest at Tromsö $\left(69^{\circ} \mathrm{N}\right)$, apparently because of the long day and rapid reproductive development. Digestibility of organic matter declined faster at higher latitude, because stem development proceeded faster and because less leaf dry matter was produced.

However paradoxically, at the same morphological stage, digestibility of the whole crop was better at higher latitude because of the better digestibility of the cell walls from the stems. Presumably rate of lignification could not keep pace with the rapid rate of stem development. So Scandinavian herbage can have a very good quality, 'despite its stemminess.

\section{Introduction}

In discussions it has been suggested that quality of herbage does not deteriorate with age as rapidly in Scandinavia as it does in more southerly Western Europe. If this be true, there might be several reasons for this.

Growth and nutritive value of herbage is affected by many external factors such as temperature, solar radiation, fertilizer, water supply, and also heritable factors such as velocity of reproductive development in spring. Lower temperature at higher latitude may cause less lignification and slower ageing as has often been found in 
greenhouse studies (e.g. Deinum \& Dirven, 1975). Van Soest et al. (1978) also suggested that differences in temperature might be responsible for different ageing patterns at different latitudes. High solar radiation and high nitrogen supply would promote herbage production, without much effect on ageing and digestibility. In addition, growing season is shorter at higher latitude, so genotypes adapted to such climates complete their reproductive cycle and age faster too. So various degrees of ageing are possible.

The pattern of ageing in spring normally proceeds as follows. At first there is little or no decline of digestibility with age, as it is still rather cold and only leaves are formed. Then during stem elongation and reproduction digestibility declines rapidly and almost rectilinearly with time. After reproduction, herbage dry mass is about 8-10 tonnes/ha and digestibility is low. It may decline a little more with age during ripening of the seed, or in occasional conditions digestibility may increase somewhat because new tillers emerge through the lodged crop. In this paper, most attention will be paid to the rapid decline in the rectilinear phase of ageing in spring.

Several papers on digestibility of grasses show such a decline in digestibility with age. In this paper, we restrict ourselves to timothy (Phleum pratense L.) and Table 1 presents some data on ageing collected from literature. Some results refer to digestibility in vivo, others to measurements in vitro, perhaps corrected with standard samples to digestibility in vivo. The decline is similar to that of other grasses. However digestibility sometimes declined a little slower with age than in other grasses (e.g. Minson et al., 1964), sometimes a little faster (Nowruzian, 1977).

There is a tendency for decline with age to increase with latitude, late varieties

Table 1. Average decline in apparent digestibility of organic matter in timothy at different sites during the rectilinear phase of ageing.

\begin{tabular}{lllll}
\hline Site & $\begin{array}{l}\text { Latitude } \\
\left({ }^{\circ} \mathrm{N}\right)\end{array}$ & $\begin{array}{l}\text { vivo or } \\
\text { vitro }\end{array}$ & $\begin{array}{l}\text { Decline } \\
\left(\% \mathrm{~d}^{-1}\right)\end{array}$ & Reference \\
Clermont-Ferrand (FR) & 44 & vivo & 0.40 & Weiss et al. (1970) \\
Nova Scotia (CA) & 46 & vitro & 0.64 & Calder \& MacLeod (1968) \\
Nova Scotia (CA) & 46 & vitro & $0.7-0.8$ & Kunelius et al. (1974) \\
Giessen (DE) & 51 & vitro & 0.45 & Nowruzian (1977) \\
Hurley (GB) & 51 & vivo & 0.41 & Minson et al. (1964) \\
Hurley (GB) & 51 & vitro & 0.39 & Terry and Tilley (1964) \\
Hurley (GB) & 51 & vitro & 0.34 & Green et al. (1971) \\
Hurley (GB) & 51 & vitro & 0.23 & Green et al. (1971) \\
Wageningen (NL) & 52 & vitro & 0.44 & Jongbloed (1973) \\
Wageningen (NL) & 52 & vitro & 0.44 & van Empel (1974) \\
Oslo (NO) & 59 & vivo & 0.47 & Homb (1953) \\
Helsinki (FI) & 58 & vitro & 0.57 & Huokuna (1978) \\
Uppsala (SE) & 59 & vivo & 0.49 & Kivimäe (1966) \\
Uppsala (SE) & 59 & vivo & 0.52 & Kivimäe (1959) \\
\hline
\end{tabular}

1 Early varieties

2 Late varieties 
showing a smaller decline than early-flowering varieties. In Canada ageing is much greater than in maritime Europe, possibly because of the steeper rise of temperature in Canada. So there seems to be a conflict between the suggestion in the first sentence of this paper and the published results, which indicate that ageing often proceeds faster at higher than at lower latitude.

To test the validity of the suggestions and to trace the origin of the contradiction a cooperative experiment was performed at various latitudes in 1977 and 1978. The results are summarized below.

\section{Materials and methods}

Timothy (Phleum pratense L.) was selected as a grass species that would produce efficiently at all sites. The best cultivar was chosen for each region.

\section{Sites}

Sufficiently large fields were available at each site (Table 2) for proper harvest of random samples on the various sampling dates.

The field in Wageningen was accidently cut on 13 May 1977, but a replacer was found at Ghent (Belgium) with the same variety. Samples from Ghent were taken from 3 June 1977 onwards. Since grass growth started at about the same time and herbage quality would be equally high in a young stage, it seemed justifiable to associate data for Wageningen and Ghent in 1977 in the lines of the various figures. The trial in Wageningen was repeated in 1978.

\section{Yield and morphological composition}

Only first growth was studied. During this uninterupted growth, herbage was sampled at intervals of 7 to 14 days. Five to ten samples of quadrats $0.25 \times 0.25 \mathrm{~m}$ were cut at about $5 \mathrm{~cm}$ height. Sampling periods were not equally long at all sites however (from 44 days at Uppsala to 73 days at Wageningen/Ghent).

Fresh and dry weight were measured at each sampling date and proportion of leaf blade, leaf sheath + stem and dead material. Dehydration was at $70{ }^{\circ} \mathrm{C}$ in forced ventilated ovens and samples were ground to pass a 1-mm sieve.

Table' 2 . General information on the various sites and on fertilizers applied.

\begin{tabular}{lrlllrrr}
\hline Site & Year & $\begin{array}{l}\text { Latitude } \\
\left({ }^{\circ}\right)\end{array}$ & Cultivar & Soil Type & $\begin{array}{l}\text { Fertilizers } \\
\left(\mathrm{kg} \mathrm{ha}^{-1}\right)\end{array}$ \\
\cline { 3 - 7 } & & & & & $\mathrm{N}$ & $\mathrm{P}$ & $\mathrm{K}$ \\
Ghent (BE) & 1977 & 51 & Erecta & sand & 80 & 51 & 120 \\
Wageningen (NL) & 1977 & 52 & Erecta & clay & 140 & 32 & 124 \\
Wageningen (NL) & 1978 & 52 & Erecta & clay & 100 & 29 & 75 \\
Landskrona (SE) & 1977 & 56 & Kämpe II & loam & 84 & 36 & 102 \\
Uppsala (SE) & 1977 & 59 & Kämpe II & clay & 100 & 49 & 91 \\
Umeå (SE) & 1977 & 64 & Engmo & silt loam & 80 & 35 & 75 \\
Tromsö (NO) & 1977 & 69 & Engmo & peat & 100 & 43 & 115 \\
\hline
\end{tabular}




\section{Chemical composition}

All chemical analysis was at Wageningen.

The morphological fractions were analysed for Kjeldahl-N, ash and water-soluble carbohydrate (wSc) with ferricyanide on an automatic analysing d/2vice. Organic cell-wall constituents (cwc) and digestibility in vitro of organic matter $\left(D_{\text {vitro }}\right)$ for ruminants were estimated by the methods of Goering \& van Soest (1970). Apparent $\left(D_{o m}\right)$ and true digestibility $\left(D_{\text {om true }}\right)$ in vivo of organic matter could be calculated from $D_{\text {vitro }}$ of standard samples of known $D_{\text {om }}$ and $D_{\text {om true }}$. Diges:ibility of cell-wall contituents $\left(\mathrm{D}_{\mathrm{cwc}}\right)$ could be calculated from content of $\mathrm{cwc}$ and $\mathrm{D}_{\mathrm{om} \text { true }}$, as digestibility of cell contents $(100-\mathrm{cwc})$ was considered complete.

This fractionation into morphological and chemical constituents, and their digestibility allow easy discovery of the factors responsible for differences in forage quality at the different latitudes.

\section{Meteorological data}

Table 3 presents weather data, averaged for each month. It shows the longer days at higher latitude. Solar radiation was low in the maritime climates of Wageningen/Ghent and of Tromsö, but higher in the more continental sites in Sweden. Temperature declined with higher latitude as expected; again, temperature was somewhat higher in continental parts of Sweden. Water supply was seldom limited.

\section{Fertilization}

Sufficient fertilizer was applied at all sites (Table 2), so that rate of production was not hampered by mineral supply.

\section{Results and discussion}

Table 4 presents some general information on production and chemical composition of the herbage at the different sites.

Table 3. Metereological data of the sites.

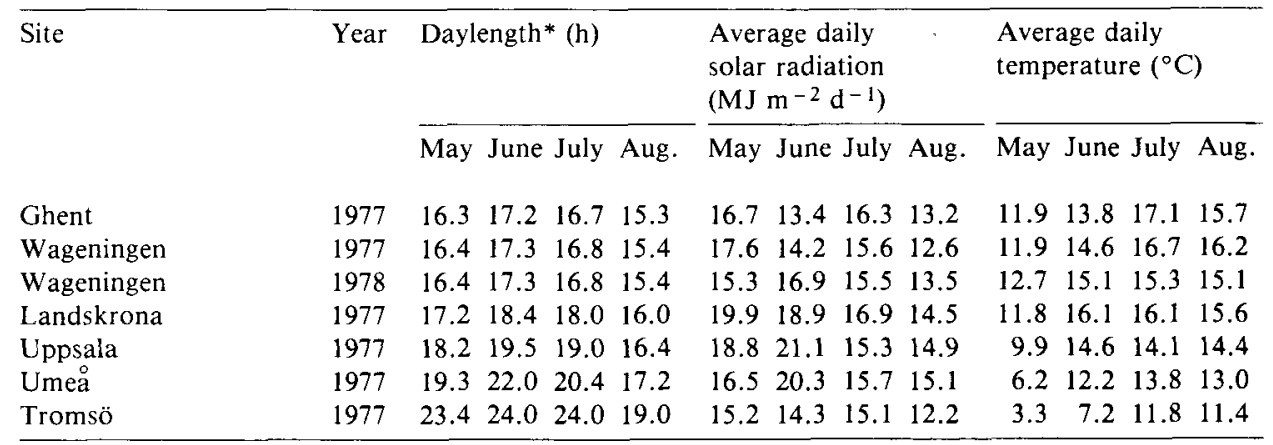

* Daylength is the time between sunrise and sunset +1 hour, except where the sun did not set. The values are hours and decimal fractions. 
Table 4. Average rate of dry-matter production during rectilinear growth and average chemical composition of timothy at the different sites (means of the different sampling dates).

\begin{tabular}{|c|c|c|c|c|c|c|c|c|}
\hline \multirow[t]{2}{*}{ Site } & \multirow[t]{2}{*}{ Sampling period } & \multirow{2}{*}{$\begin{array}{l}\text { Rate of production } \\
\text { of dry matter } \\
\left(\mathrm{g} \mathrm{m}^{-2} \mathrm{~d}^{-1}\right)\end{array}$} & \multicolumn{4}{|c|}{$\begin{array}{l}\text { Content of } \\
\text { dry matter }(\%)\end{array}$} & \multicolumn{2}{|c|}{ Digestibility } \\
\hline & & & $\mathrm{N}$ & wsc & ash & cwc & om & cwc \\
\hline Wageningen/Ghent & 2 May-14 July & 19.3 & 1.99 & 8.9 & 6.4 & 62.4 & 68.4 & 53.4 \\
\hline Wageningen 1978 & 26 April-19 June & 13.4 & 1.97 & 7.4 & 7.6 & 57.8 & 77.5 & 64.0 \\
\hline Landskrona & 9 May-27 June & 15.5 & 3.27 & 10.1 & 10.4 & 50.1 & 77.0 & 58.4 \\
\hline Uppsala & 19 May-1 July & 14.3 & 2.17 & 14.7 & 7.4 & 52.2 & 76.0 & 57.4 \\
\hline Umeå & 6 June-26 July & 18.6 & 2.00 & 12.1 & 7.4 & 58.3 & 73.3 & 57.6 \\
\hline Tromsö & 27 June-15 August & 25.1 & 1.63 & 13.8 & 5.5 & 60.1 & 71.0 & 54.4 \\
\hline
\end{tabular}

Sampling at Wageningen/Ghent in 1977 was over a much longer period then elsewhere. This and the few samplings of the early stages of growth caused the low average digestibility.

\section{Dry-matter production}

Average rate of dry-matter production during rectilinear growth ranged from 13 to $19 \mathrm{~g} \mathrm{~m}^{-2} \mathrm{~d}^{-1}$ (Table 4), which is in fair agreement with the rates normally found in

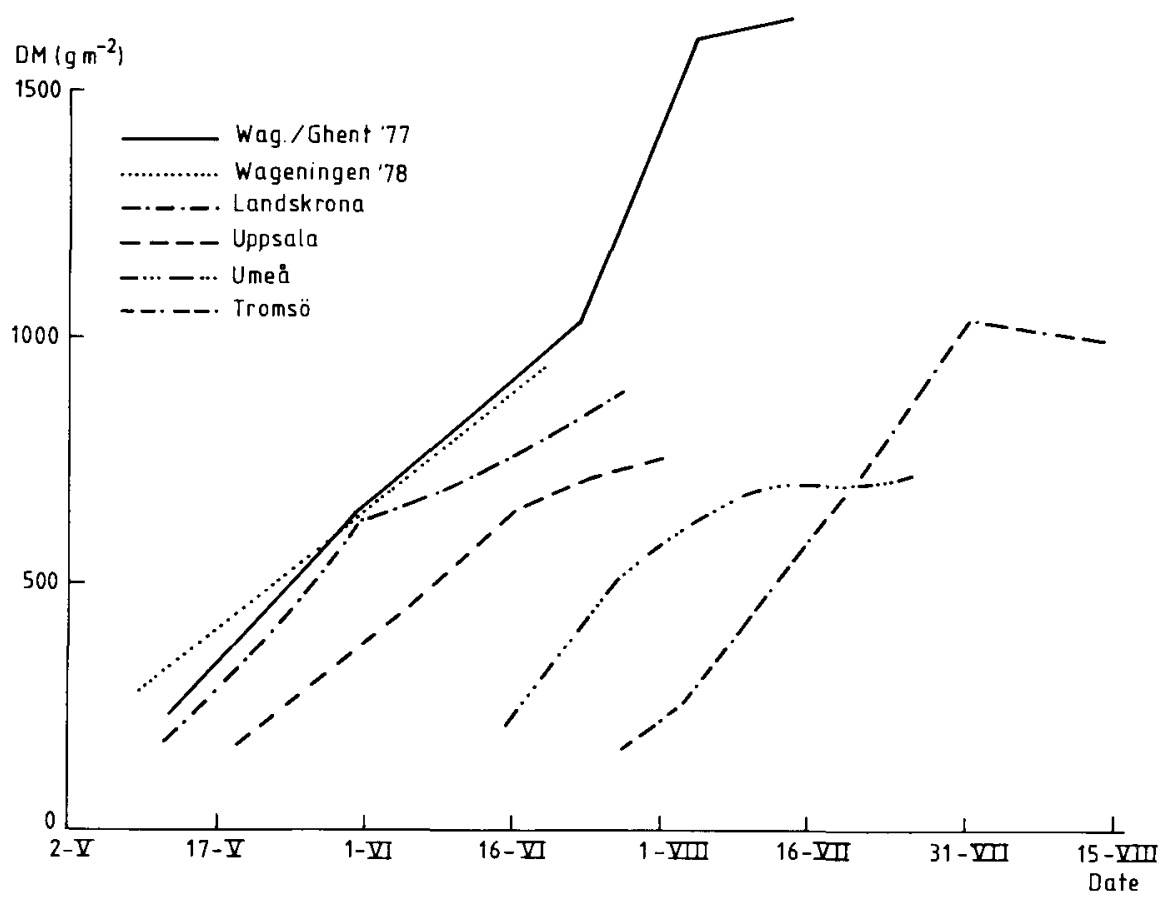

Fig. 1. Production curves of timothy at the different sites.

Neth. J. agric. Sci. 29 (1981) 
spring (Alberda \& Sibma, 1968). The small area of $0.0625 \mathrm{~m}^{2}$ and the limited number of samples taken on a sampling date did not permit firm conclusions. So yield data have to be considered with great care. However rate of production at Tromsö was higher, even where solar radiation and temperature were low. Maybe the long day and the need for completion of the reproductive cycle in a very short time accelerated rate of production considerably. Almost as high a rate was reached in other trials at Tromsö (Østgård, 1962). Final yield at Ghent seemed extremely high, up to $1600 \mathrm{~g} \mathrm{~m}^{-2}$, which has never been reached in grass in a single cut. This may be due to sampling errors. Fig. 1 shows the production curves at the various sites.

Standard errors in morphological and chemical composition will be smaller than those in yield as they depend less on sample size.

\section{Morphological development}

Fig. 2 presents the proportion of leaf against age. It decreased rapidly at all sites as expected, in the initial stages of growth. Later the decline was smaller. Ears emerged at all sites when proportion of leaf was about $50 \%$.

\section{Chemical composition}

Table 4 also presents the average chemical composition of the herbage at the sites. Nitrogen content was highest at Landskrona and lowest at Tromsö, perhaps because of differences in nitrogen supply from the soil. Differences in average content of wsc were only partly correlated with nitrogen content, presumably because solar radiation, temperature and reproductive development may have interfered.

Average content of cwc tended to be higher at higher latitude, whereas digestibility tended to be lower. The very high content of $\mathrm{cwc}$ and the low $\mathrm{D}_{\mathrm{om}}$ of Wageningen/Ghent are certainly caused by the few samples at early age and the greater number of samples at late stages of growth.

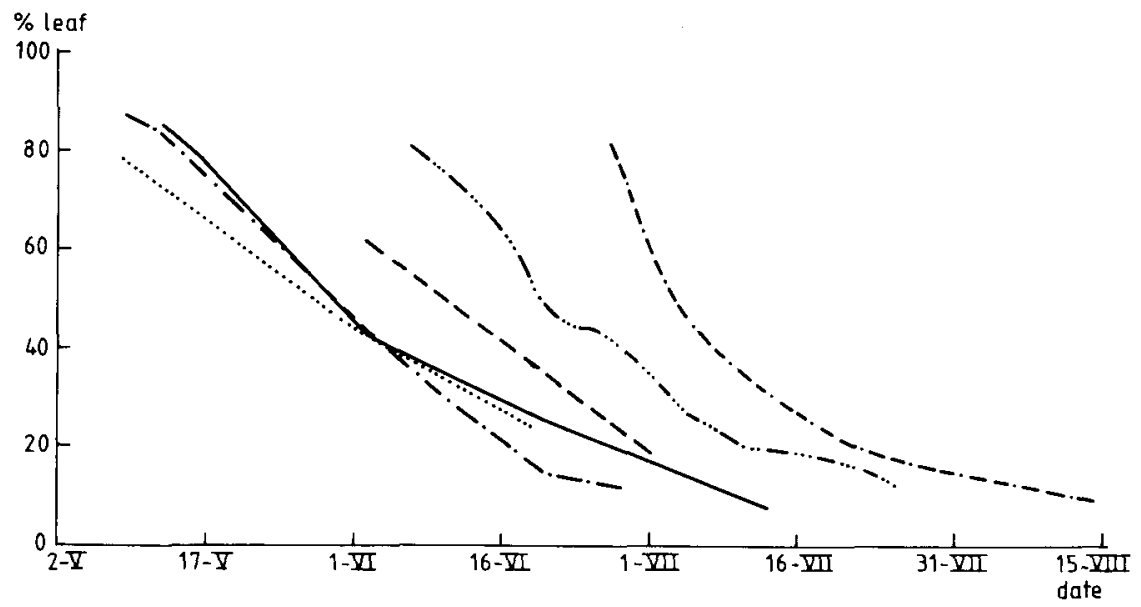

Fig. 2. Course of proportion of leaf blade (\%) with age at the different sites (legends as in Fig. 1). 


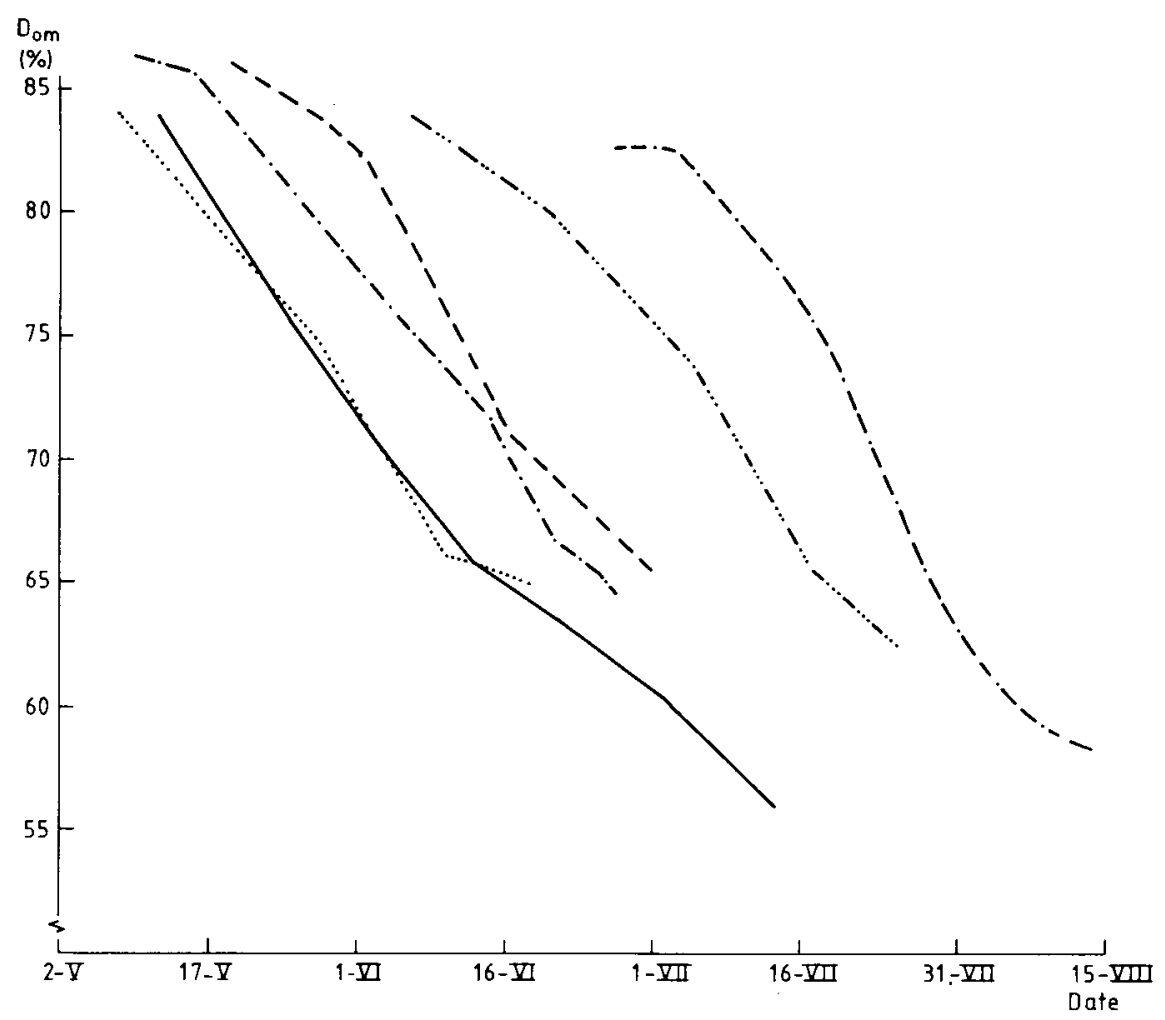

Fig. 3. Course of apparent digestibility of organic matter $(\%)$ with age at the different sites (legends as in Fig. 1).

\section{Dynamics of digestibility of organic matter}

Digestibility of organic matter along with content of crude protein are quality criteria of roughage for ruminants. Fig. 3 presents apparent digestibility of organic matter against age at the different sites. It shows that digestibility always declined as expected. This decline was rather linear at most sites except at the very beginning, and in the very end, when rates of grass production were small.

Average decline of digestibility with age in percentage units per day at the different latitudes is presented in Table 5 during the linear phase. For the whole crop (leaf + stem + dead) it was greater at higher latitude, as in the published data (Table 1).

As digestibility of the crop may be considered the result of digestibility of leaf, leaf sheath + stem and dead material, corrected for their contribution to the yield of organic matter, these dynamics in whole crop digestibility originate from the dynamics of digestibility of the various tissues. Leaf digestibility tended to decline somewhat slower at high latitude, perhaps because of the lower temperature (Table 5). However stem digestibility declined more rapidly at higher latitude, because of 


\section{B. DEINUM ET AL.}

Table 5. Average rate of decline in digestibility $\left(\mathrm{D}_{\mathrm{om}}\right)$ during the rectilinear phase and digestibility for 50 and $70 \%$ leaf sheath + stem.

\begin{tabular}{|c|c|c|c|c|c|}
\hline \multirow[t]{2}{*}{ Site } & \multicolumn{3}{|c|}{ Rate of decline $\left(\% \mathrm{~d}^{-1}\right)$} & \multicolumn{2}{|c|}{$\begin{array}{l}\text { Digestibility }(\%) \text { for the content } \\
\text { of leaf sheath }+ \text { stem }\end{array}$} \\
\hline & leaf & $\begin{array}{l}\text { leaf sheath } \\
+ \text { stem }\end{array}$ & total & $50 \%$ & $70 \%$ \\
\hline Wageningen/Ghent 1977 & 0.19 & 0.52 & 0.45 & 75.0 & 59.0 \\
\hline Wageningen 1978 & 0.22 & 0.55 & 0.46 & 75.5 & 59.0 \\
\hline Landskrona & 0.19 & 0.54 & 0.47 & 78.2 & 65.8 \\
\hline Uppsala & 0.14 & 0.53 & 0.48 & 77.5 & 68.8 \\
\hline Umeå & 0.18 & 0.70 & 0.58 & 80.5 & 68.8 \\
\hline Tromsö & 0.12 & 0.64 & 0.65 & 83.0 & 76.0 \\
\hline
\end{tabular}

the faster reproductive development in the shorter season of higher-latitude regions. This faster development is also reported by Harkess \& Alexander (1969) and by $\mathrm{Hu}-$ okuma (1978).

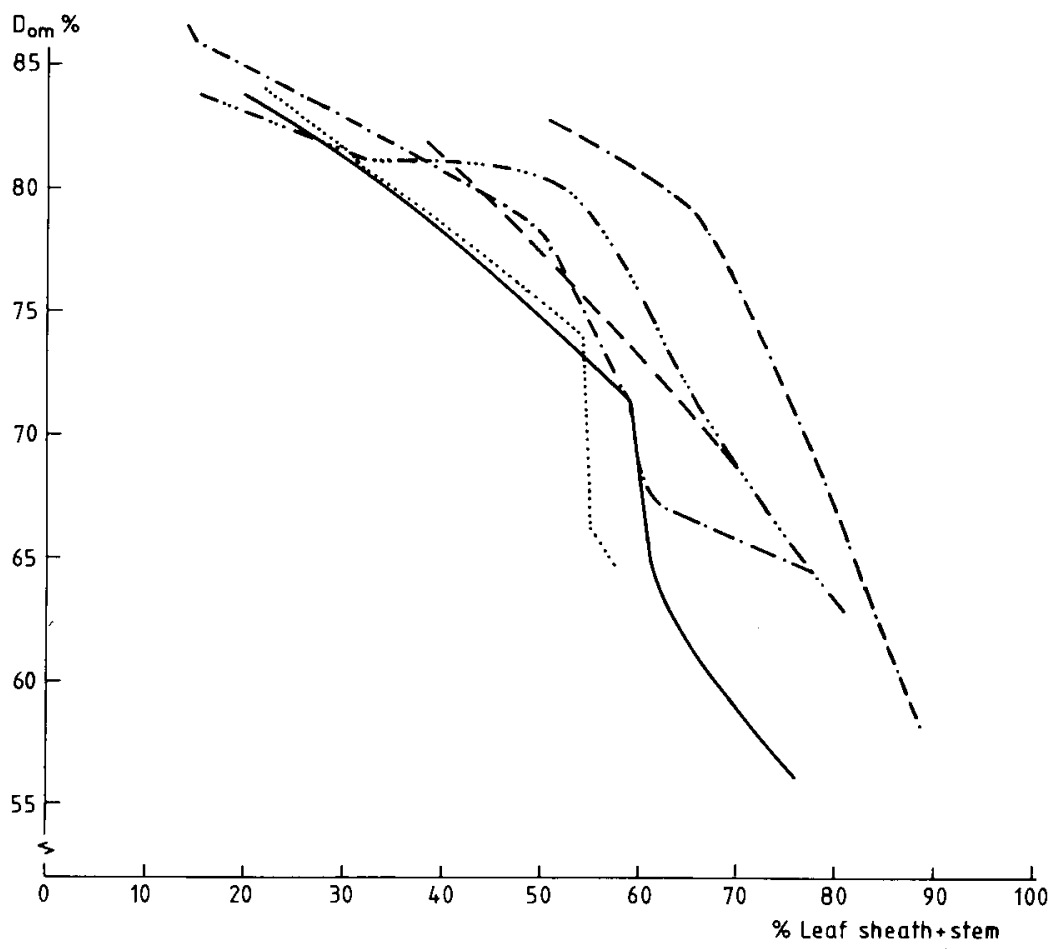

Fig. 4. Course of apparent digestibility of organic matter $(\%)$ with proportion of leaf sheath + stem $(\%)$ at the different sites (legends as in Fig. 1). 


\section{Digestibility and reproductive development}

The present results suggest that digestibility declined faster at higher latitude together with the faster reproductive development. So the question arises whether digestibility and reproduction are related. By taking percentage of leaf sheath + stem as and indicator of reproductive development, we found (Fig. 4) that the lines did not cover each other. With the same percentage of leaf sheath + stem, digestibility $\left(D_{o m}\right)$ of the whole crop was higher at higher latitude. For instance, at Wageningen digestibility was $75 \%$ with $40 \%$ of leaf sheath + stem, whereas the same digestibility was found at Tromsö with $70 \%$ of leaf sheath + stem. So digestibility in Scandinavia is much higher than in the low countries at the same morphological stage (Table 5).

There is thus a paradox that though ageing is faster in Scandinavia than in the low countries, digestibility is better in Scandinavia at the same morphological stage. This must certainly be ascribed to the very rapid reproduction at higher latitude. These aspects of $D_{o m}$ were also found in $D_{c w c}$, which is usually rather well correlated with lignin content of cell walls. At the same morphological stage, lignin content of the herbage would be lower at higher latitude. Perhaps lignification cannot keep pace with the very rapid stem development of the grasses in these cooler regions. These results and suggestions are in good agreement with those of Harkess \& Alexander (1969) who found that digestibility of young timothy and other grasses were higher in Scotland than in the south of England, that the decline with age was greater in Scotland but that digestibility was better at the same morphological stage.

Leaf production too tended to be lower at higher latitude. It amounted to about $300 \mathrm{~g} \mathrm{~m}^{-2}$ at Wageningen and Landskrona, $250 \mathrm{~g} \mathrm{~m}^{-2}$ at Uppsala, $200 \mathrm{~g} \mathrm{~m}^{-2}$ at Umeå and only $150 \mathrm{~g} \mathrm{~m}^{-2}$ at Tromsö. As reproductive development was faster at higher latitude, leaf production presumably was finished sooner. So the greater ageing at higher latitude is also caused by the smaller contribution of leaves.

\section{References}

Alberda, Th. \& L. Sibma, 1968. Dry-matter production and light interception of crop surfaces. 3. Actual herbage production in different years as compared with potential values. J. Brit. Grassland Soc. 23: 206-216.

Calder, F. W. \& L. B. MacLeod, 1968. In vitro digestibility of forage species as affected by fertilizer application, stage of development and harvest dates. Canad. J. Pl. Sci. 48: 17-24.

Deinum, B. \& J. G. P. Dirven, 1975. Climate, nitrogen and grass. 6. Comparison of yield and chemical composition of some temperature and tropical grass species grown at different temperatures. Neth. J. agric. Sci. 23: 69-82.

Empel, G. van, 1974. Verandering van de verteerbaarheid en enkele andere factoren bij veroudering van gras en luzerne in het voorjaar. Internal report, $44 \mathrm{pp}$. (In Dutch.)

Goering, H. K. \& P. J. van Soest, 1970. Forage fibre analysis. Agricultural Handbook USDA 379, 22 pp.

Green, J. O., A. J. Corrall \& R. A. Terry, 1971. Grass species and varieties. Relationships between stage of growth, yield and forage quality. Tech. Rep. Grassland Res. Inst. Hurley No. 8, 81 pp.

Harkess, R. D. \& R. H. Alexander, 1969: The digestibility and productivity of selected herbage varieties. J. Brit. Grassland Soc. 24: 282-289. 


\section{B. DEINUM ET AL.}

Homb, Th., 1953. Chemical composition and digestibility of grassland crops. Acta Agric. scand. 3: 1-32. Huokuna, E., 1978. Factors limiting the optimum grass yield in Northern Europe. Proc. 7th gen. Meet. Eur. Grassland Fedn (Ghent) 3.1-3.11.

Jongbloed, A. W., 1973. De invloed van maaidatum en enkele andere faktoren op de verteerbaarheid van gras. Internal report, $60 \mathrm{pp}$. (In Dutch.)

Kivimäe, A., 1959. Chemical composition and digestibility of some grassland plants. Acta Agric. scand. Suppl. 5, 142 pp.

Kivimäe, A., 1966. Estimation of digestibility and feeding value of timothy. Proc. 10th int. Grassland Congr. (Helsinki) 389-393.

Kunelius, H. T., L. B. MacLeod \& F. W. Calder, 1974. Effects of cutting management on yield, digestibility, crude protein and persistency of timothy, bromegrass and orchard grass. Canad. J. Pl. Sci. 54: 55-64.

Minson, D. J., C. E. Harris, W. F. Raymond \& R. Milford, 1964. The digestibility and voluntary intake of S22 and H1 Ryegrass, S170 Tall Fescue, S48 Timothy, S215 Meadow Fescue and Germinal Cocksfoot. J. Brit. Grassland Soc. 19: 298-305.

Nowruzian, H., 1977. Vergleichende Untersuchungen der Verdaulichkeit von Gras- und Kleearten und -Sorten in Abhängigkeit von Entwicklungsstadium. Dissertation, Giessen, 122 pp.

Ostgård, O., 1962. Different cutting times in timothy. Forskning og Forsøk $i$ Landbruket 13: 13-56.

Soest, P. J. van, D. R. Mertens \& B. Deinum, 1978. Preharvest factors influencing quality of conserved forage. J. Anim. Sci. 47: 712-720.

Terry, R. A. \& J. M. A. Tilley, 1964. The digestibility of the leaves and stems of perennial ryegrass, cocksfoot, timothy, tall fescue, lucerne and sainfoin as measured by an in vitro procedure. J. Brit. Grassland Soc. 19: 363-372.

Weiss, Ph. \& C. Demarquilly, 1970. Valeur alimentaire des fourrages verts. Fourrages 42: 3-22. 